\section{Associated factors to self-rated health among hypertensive and/ or diabetic elderly: results from Bambuí project}

\author{
Fatores associados à autoavaliação \\ negativa da saúde entre idosos \\ hipertensos e/ou diabéticos: \\ resultados do projeto Bambuí
}

\section{Abstract}

Objective: This study investigated the associated factors with negative self-rated health among hypertensive and/or diabetic elderly. Methods: All the participants of Bambuí Project elderly cohort who suffered from hypertension and/or diabetes and who answered the questionnaire without the help of a close informant were selected for this ( $\mathrm{n}=942)$. Covariates encompassed sociodemographic characteristics, social support, health behaviors, health status and use of health services. Results: Negative self-rated health showed positively associated with dissatisfaction with social relations (PR $=1.98,95 \% \mathrm{CI} 1.42-2.76)$, attendance at religious services less than once a month $(\mathrm{PR}=1.96,95 \% \mathrm{CI} 1.44-2.68$; be smokers ( $\mathrm{PR}=1.64,95 \% \mathrm{CI} 1.24-2.17)$, presence of arthritis (PR $=1.35,95 \% \mathrm{CI} 1.07$ - 1.71), depressive symptoms $(\mathrm{PR}=1.81$, $95 \% \mathrm{CI} 1.37-2.39)$ and insomnia $(\mathrm{PR}=1.37$, 95\%CI 1.06 - 1.78), having consulted the doctor two or more times in the last twelve months (PR $=2.18$; 95\%CI $1.14-4.19$ and $\mathrm{PR}=3.96 ; 95 \% \mathrm{CI} 2.10-7.48$, respectively for " 2 - 3" and " $4+$ " visits), and have hypertension and diabetes (compared to the isolated presence of hypertension) Conclusions: Our results confirmed the multidimensional nature of self-rated health and were consistent with that observed in other national and international studies.

Keywords: Aged. Hypertension. Diabetes. Health self-assesment.

\author{
Antônio Ignácio de Loyola Filho',"1 \\ Josélia de Oliveira Araújo Firmo' \\ Elizabeth Uchôa' \\ Maria Fernanda Lima-Costa' \\ 'Center for Studies in Public Health and Aging, Center for Research René \\ Rachou/Oswaldo Cruz Foundation and Universidade Federal de Minas Gerais - \\ Belo Horizonte (MG), Brazil. \\ "Department of Applied Nursing, School of Nursing, Universidade Federal de \\ Minas Gerais - Belo Horizonte (MG), Brazil.
}

Corresponding author: Antônio Ignácio de Loyola Filho. Avenida Augusto de Lima 1715, 60 andar, CEP: 30190-003, Belo Horizonte, MG, Brazil. E-mail: aloy@cpqrr.fiocruz.br

Source of funding: FINEP (Financiadora de Estudos e Projetos) - Protocol no. 66940009-00. Conflict of interests: nothing to declare. 


\section{Resumo}

Objetivo: O presente estudo teve como objetivo investigar os fatores associados à autoavaliação negativa da saúde entre idosos hipertensos e/ou diabéticos.

Metodologia: Foram selecionados para o presente estudo todos os idosos integrantes da linha base da coorte do Projeto Bambuí, que sofriam de hipertensão e/ou diabetes e que responderam o questionário sem ajuda de informante próximo ( $n=942$ ). As covariáveis englobaram características sociodemográficas, recursos sociais, comportamentos relacionados à saúde, condições de saúde e de utilização de serviços de saúde. Resultados: A pior autoavaliação da saúde apresentou-se positivamente associada à insatisfação com as relações sociais ( $\mathrm{RP}=1,98$; IC95\% 1,42 - 2,76), frequência a cultos religiosos menor que uma vez ao mês $(\mathrm{RP}=1,96$; IC95\% 1,44 - 2,68; ser tabagista $(\mathrm{RP}=1,64$; IC95\% 1,24 - 2,17), presença de artrite $(\mathrm{RP}=1,35$; IC95\% 1,07 - 1,71), sintomas depressivos ( $\mathrm{RP}=1,81$; IC95\% 1,37 - 2,39) e insônia (RP = 1,37; IC95\% 1,06 - 1,78), ter consultado o médico duas ou mais vezes nos últimos doze meses ( $\mathrm{RP}=2,18$; IC95\% $1,14-4,19$ e RP = 3,96; IC95\% 2,10 - 7,48, respectivamente para " 2 - 3 " e " $4+$ " consultas) e ser hipertenso e diabético (comparado à presença isolada de hipertensão, RP = 1,43; IC95\% 1,07 - 1,92). Conclusões: Nossos resultados confirmaram o caráter multidimensional da autoavaliação da saúde e apresentaram-se consistentes com o observado em outros estudos nacionais e internacionais.

Palavras-chave: Idoso. Hipertensão. Diabetes. Self-rated health.

\section{Introduction}

Aging in the Brazilian population in recent years is unquestionable, and has been happening quickly ${ }^{1}$. Because this population segment experiences illness and disability more frequently and intensively and uses more health services, there has been a growing scientific interest in the impact of this process on the pattern of morbidity and mortality of the Brazilian population $^{2,3}$.

Hypertension and diabetes are common diseases, and have a significantly increased prevalence in those with advancing age $\mathrm{e}^{4}$ The course of these diseases could go out of control and that contributes to the emergence of new diseases and the worsening of the health of their carriers: hypertension is a risk factor for the occurrence of other cardiovascular diseases such as myocardial infarction, heart failure and vascular-cerebral accident, besides kidney disease $^{5}$. In turn, complications associated with diabetes include retinopathy (with possible loss of vision), nephropathy (which can lead to renal failure) and peripheral neuropathies (which can lead to leg ulcers and even amputation $)^{6}$.

Self-rated health is a subjective, robust and comprehensive measure of the health condition of the individual, which is easily performed ${ }^{7}$. It gathers and summarizes information about health and life context of the individual, reflecting biological, psychological and social factors ${ }^{8}$. Its strength as a measure of health arises from the possibility of capturing symptoms of undiagnosed diseases, incorporating judgments about disease severity and outcome of health condition $^{7}$. In epidemiological studies, it has been a consistent predictor of mortality, independent of the presence of health conditions defined objectively. This also seems to apply to relatively less healthy populations, with specific illnesses. For example, among individuals with cardiovascular disease, the negative self-rated health was associated with a higher risk of mortality from all causes, regardless of 
the presence of other health conditions. A similar association was found between subjects who developed diabetes later (at the age of 30 or later $)^{10}$.

Self-rated health may also reflect the availability of internal (motivations) and external (social) resources to deal with the disease ${ }^{7}$. Therefore, it is plausible to assume that knowing the characteristics associated with self-rated health among patients with chronic conditions (such as hypertension and diabetes) allows doctors not only to know the opinions of patients about the level of their own health, but also to assess the degree of propensity for disease control by individuals and their coping, and therefore identify those who are at higher risk of worsening their condition.

Population-based epidemiological investigations focused on self-rated health among elderly Brazilians are still scarce. They point to the existence of a multidimensional aspect ${ }^{11}$ in the structure of self-rated health, both for the elderly residents of big cities ${ }^{12}$ and for those living in small towns ${ }^{11,13}$. In São Paulo, the sociodemographic characteristics (gender, age, living alone, marital status, education and income) and health conditions (number of chronic conditions and functional capacity) were associated with self-rated health. Demographic characteristics (age, among men) and health conditions (risk of malnutrition among men, hypertension among women and disability in both genders) were positively associated with negative self-rated health among elderly living in the countryside in three distinct Brazilian regions ${ }^{13}$. In Bambuí, Minas Gerais, the multidimensional structure of self-rated health showed to be a broader one, incorporating, in addition to socioeconomic characteristics (income) and specific health conditions (depressive symptoms and sleep disturbances), aspects linked to social resources (degree of satisfaction with their personal relationships) and the use of health services (number of medical consultations and problems when needing to access these services, use of prescribed medications and history of hospitalization $)^{11}$. An additional study with elderly Bambuí residents also demonstrated that the components of the self-rated health structure may vary depending on the context, because dissatisfaction with social relationships and use of health services were most important for self-rated health among older people with lower income than having experienced health problems and difficulties in accessing health services ${ }^{14}$.

However, to our knowledge, the determinants of self-rated health have not yet been investigated among the Brazilian elderly patients with hypertension and/or diabetes. Based on what has been exposed so far, this exploratory study investigated which characteristics were associated to the subjective health self-rating among elderly with the above mentioned diseases.

\section{Methodology}

This research is a part of the Bambuí project, a longitudinal study on aging and health, developed in the homonymous municipality, located in the western region of the State of Minas Gerais, which had a population of 20,573 inhabitants in 1997 . The population of Bambuí remained stable between the decades of 1971 and 1990. In the same period, life expectancy increased from 59.9 to 70.2 years. Cardiovascular diseases were the leading cause of death in 1991 and the second cause of admittance to public hospitals in 1993. In 1997, the city population was surveyed by the research team linked to the project. All citizens aged 60 or older were selected for the baseline cohort. The census identified 1,742 senior citizens eligible for the study, of whom 1,606 (92.2\%) were interviewed and 1,496 (85.9\%) were examined (blood tests, laboratory tests, physical tests and electrocardiogram). The elderly population interviewed and examined showed to be similar to the elderly population surveyed by the census in terms of gender, age, marital status, family income and education. Further details can be found in another publication ${ }^{15}$. 
For this study, all elderly patients who were part of the baseline cohort of Bambuí project, who suffered from hypertension and/or diabetes and who answered the questionnaire without the aid of a close informant at the baseline of the study were selected ${ }^{15}$. Elderly individuals who had values greater than or equal to 140/90 $\mathrm{mmHg}$, respectively, for systolic and diastolic pressure, and/or reported use of antihypertensive medication, were considered as hypertensive ${ }^{5}$. The blood pressure measurements were obtained with the subject seated, after 5 minutes of rest and considering a hiatus of 30 minutes from smoking cigarettes and/or drinking caffeine. Three measures of blood pressure were made, and the values resulting from the arithmetic mean between the second and third measurements were used. To sort a patient as diabetic, plasma glucose values greater than or equal to $126 \mathrm{~mm} / \mathrm{dL}$ and/or reference to the use of anti-diabetic drugs were used ${ }^{6}$. The values for blood sugar were provided by biochemical tests. All information on the use of medicines was obtained through a questionnaire ${ }^{15}$.

The self-rated health (dependent variable) was measured by the answer to the question "At the present moment, you consider your health: very good, good, fair, poor or very poor?" For the stage of data analysis, the variable was dichotomized: the "bad/very bad" answers were grouped in the category of negative rating and the other answers made up the positive rating category.

In the investigation of factors associated with self-rated health, socio-demographic characteristics, social resources, healthrelated behaviors, indicators of health condition and utilization of health services were considered. The socio-demographic characteristics were: gender, age (age groups were: 60 - 69, 70 - 79 and 80+), marital status (married/living with partner, widowed and single/separated), education in years of schooling (none, $1-3$ and 4+) and monthly family income in number of minimum wages $(<2.2-3.9$ and $>4)$. Social resources investigated were: the degree of satisfaction with social relationships (satisfied, indifferent and dissatisfied) and frequency of attendance to religious cults (1 or more per week; 1 - 3 times a month and less than 1 time per month).

With regard to health-related behaviors, we investigated the frequency of physical exercise in leisure time in the past 90 days ( $<3$ times per week versus $\geq 3$ times per week), smoking history (never smoked, former smoker, current smoker) and frequency of drinking (did not drink/never drank; $<3$ times per week and $\geq 3$ times a week).

Indicators of health status included: coronary heart disease, arthritis/rheumatism, presence of antibodies to Trypanosoma cruzi, symptoms of depression and anxiety (last 15 days), insomnia (last 30 days), and cognitive dysfunction. The participant's status in relation to hypertension and diabetes was also analyzed, based on three categories: being only hypertensive, being only diabetic and being both hypertensive and diabetic. The reported medical diagnosis was considered for coronary heart disease (angina and/or myocardial infarction) and arthritis/rheumatism. The presence of antibodies to T. cruzi was detected through hemagglutination reactions and ELISA, considering the individual who presented reaction in both tests $^{15}$ as positive. The presence of depression and anxiety symptoms was identified by applying the 12-question version of the General Health Questionnaire $(\mathrm{GHQ})^{16}$, validated in Brazill ${ }^{17}$, with the cohort $\geq 4$ being adopted for a positive rating by the respondent. In a previous study of this population, it was observed that the GHQ-12 showed the same ability to detect depressive symptoms as the GDS- $30^{18}$. In addition, GHQ-12 has the ability to trace other common mental disorders such as anxiety and somatoform disorder ${ }^{16}$. The presence of insomnia was defined in individuals who reported difficulty in initiating or maintaining sleep and/or waking up before time, with a frequency of 3 times a week in the last 30 days, and which resulted in prejudice to their functions ${ }^{19}$. The participant who had a score of 
less than 22 for the mini-mental examination was classified as positive for cognitive dysfunction ${ }^{20,21}$. Still on health conditions, consumption of prescription drugs was included as a marker for the presence of other health conditions than those specified above. To evaluate functionality, the patients' reports of inability to perform at least one of the basic activities of daily living - BADLs (dressing up, eating, lying down/getting up from bed and/or chair, using the bathroom and moving through the rooms of the house) - was considered.

Regarding the use of health services, the following variables were considered: history of hospital admission (yes or no), number of physician visits in the past 12 months (none, $1,2-3,4+$ ), health plan coverage (yes or no) and reporting of the main problem faced when in need of medical services ("had no problem"; "distance or price of consultation or long queue for scheduling" and "other").

The characteristics of the elderly that negatively self-rated their health were compared to those who self-rated it positively, using the chi-square test for this purpose. The variables, indicating the level of analysis, showed to be associated with self-rated health at the level of statistical significance $\mathrm{p}<0.20$, were selected for inclusion in the multivariate model. The multivariate analysis was performed based on the Poisson regression model, which provided estimates of adjusted prevalence ratios and their respective 95\% robust confidence intervals ${ }^{22}$. Variables that remained associated with the event to the significance level of $p<0.05$ in the multivariate model were retained in the final model and considered independently associated with the event under investigation. The statistical package used in the analysis was Stata ${ }^{\circledR}$, v. 10.

This research was carried out while respecting the ethical principles of human research and was approved by the Ethics Committee of the Oswaldo Cruz Foundation. There are no conflicts of interest of authors with the funding agencies or otherwise.

\section{Results}

Among the elderly that composed the baseline of Bambuí project $(n=1,606), 942$ were hypertensive and/or diabetic and were included in this study. Of this total, $730(77.5 \%)$ were only hypertensive, 62 (6.6\%) were only diabetic and 150 (15.9\%) were both hypertensive and diabetic. Most participants were female (618 or $65.6 \%$ ) and had a mean age of 68.9 years (ranging between 60 and 93 years). Of the total, 450 (47.8\%) were married, 345 (36.6\%) were widowed and $147(15.6 \%)$ were single or separated; low education and low family income predominated: $63.7 \%$ had less than four years of regular school attendance and two thirds were members of families with total income lower than four minimum wages at the time of the survey (1 Minimum Wage $=\mathrm{R} \$ 120$, approximately US $\$ 110$ at the time of this study).

The proportion of elderly who negatively self-rated their health was $20.1 \%(n=189)$. Table 1 shows the results of univariate analyses for the sociodemographic characteristics and social resources associated with self-rated health. Among the socio-demographic characteristics, only education and family income (both $\mathrm{p}<0.001$ ) were significantly associated with the event, and the elderly with lower income and lower education negatively self-rated their own health in comparison to those with higher education and income. Females, those in the younger age group (60 - 69 years) and widows self-rated their health worse, but the results were not significant. With regard to social resources, all variables showed a significant association ( $\mathrm{p}<0.05)$ with self-rated health, and negative self-rating was more significantly prevalent among those dissatisfied with social relationships and those who attended less religious cults.

All health behavior variables were associated with self-rated health, at the level of $\mathrm{p}<0.05$. Hypertensive and/or diabetic elderly who practiced physical exercises 
Table 1 - Distribution of self-rated health among hypertensive and/or diabetic elderly, according to socio-demographic characteristics and social resources, Bambuí, Minas Gerais, 1997.

Tabela 1 - Distribuição da autoavaliação da saúde entre idosos hipertensos e/ou diabéticos, segundo características sociodemográficas e recursos sociais, Bambuí, Minas Gerais, 1997.

\begin{tabular}{|c|c|c|c|c|c|}
\hline \multirow{3}{*}{ Variables } & \multicolumn{4}{|c|}{ Self-rated health } & \multirow{3}{*}{$\mathrm{p}$-value } \\
\hline & \multicolumn{2}{|c|}{ Negative } & \multicolumn{2}{|c|}{ Positive } & \\
\hline & $\mathrm{n}$ & $\%$ & $\mathrm{n}$ & $\%$ & \\
\hline \multicolumn{6}{|l|}{ Socio-demographic characteristics } \\
\hline \multicolumn{6}{|l|}{ Gender } \\
\hline Male & 62 & 19.1 & 262 & 80.9 & \\
\hline Female & 127 & 20.6 & 491 & 79.5 & 0.607 \\
\hline \multicolumn{6}{|l|}{ Age (years) } \\
\hline $60-69$ & 118 & 21.2 & 439 & 78.8 & \\
\hline $70-79$ & 54 & 18.0 & 246 & 82.0 & \\
\hline$\geq 80$ & 17 & 20.0 & 68 & 80.0 & 0.540 \\
\hline \multicolumn{6}{|l|}{ Marital status } \\
\hline Married / Living with partner & 84 & 18.7 & 366 & 81.3 & \\
\hline Widowed & 79 & 22.9 & 266 & 77.1 & \\
\hline Single / Separated & 26 & 17.7 & 121 & 82.3 & 0.247 \\
\hline \multicolumn{6}{|c|}{ Education (in years of school attendance) } \\
\hline None & 82 & 28.3 & 208 & 71.7 & \\
\hline $1-3$ & 58 & 18.7 & 252 & 81.3 & \\
\hline 4 or + & 49 & 14.3 & 293 & 85.7 & $<0.001$ \\
\hline \multicolumn{6}{|c|}{ Family income (in number of Minimum Wages) ${ }^{\mathrm{b}}$} \\
\hline$<2$ & 82 & 30.9 & 183 & 69.1 & \\
\hline $2-3.9$ & 68 & 19.3 & 285 & 80.7 & \\
\hline$\geq 4$ & 37 & 11.6 & 282 & 88.4 & $<0.001$ \\
\hline \multicolumn{6}{|l|}{ Social resources } \\
\hline \multicolumn{6}{|c|}{ Level of satisfaction with social relations } \\
\hline Satisfied & 153 & 18.3 & 685 & 81.7 & \\
\hline Indifferent & 13 & 25.0 & 39 & 75.0 & \\
\hline Dissatisfied & 23 & 44.2 & 29 & 55.8 & $<0.001$ \\
\hline \multicolumn{6}{|l|}{ Attendance to religious cults } \\
\hline Once a week or more & 57 & 14.2 & 345 & 85.8 & \\
\hline $1-3$ times a month & 72 & 21.0 & 271 & 79.0 & \\
\hline Less than once a month & 58 & 30.7 & 131 & 69.3 & $<0.001$ \\
\hline
\end{tabular}

${ }^{\mathrm{a}}$ Obtained by Chi-square Pearson; ${ }^{\mathrm{b}}$ National Minimum Wage at the time $=\mathrm{R} \$ 120.00$. a Obtido pelo teste do Qui-Quadrado de Pearson; ${ }^{\circ}$ Salário Mínimo à época $=R \$ 120,00$.

more frequently $(\mathrm{p}=0.005)$ positively self-rated their health. Alternatively, smokers and former smokers $(\mathrm{p}<0.001)$ negatively self-rated their health. Alcohol consumption was associated with self-rated health, but the difference was significant only in the elderly who drank alcohol less than three times a week, who positively selfrated their health in comparison to those who never drank or did not do it in the last 12 months (Table 2).
Results for the univariate analyses of health conditions and functional capacity are shown in Table 3. With the exception of coronary disease and the participant's status in relation to hypertension/diabetes, all other health conditions showed to be associated $(\mathrm{p}<0.05)$ to the event under investigation. Negative self-rated health was also more prevalent among elderly with disabilities for at least one BADL $(\mathrm{p}<0.001)$.

Regarding characteristics related to the utilization of health services, the prevalence 
Table 2 - Distribution of self-rated health among hypertensive and /or diabetic elderly, according to health behaviors, Bambuí, Minas Gerais, 1997.

Tabela 2 - Distribuição da autoavaliação da saúde entre idosos hipertensos e/ou diabéticos, segundo comportamentos de saúde, Bambuí, Minas Gerais, 1997.

\begin{tabular}{|c|c|c|c|c|c|}
\hline \multirow{3}{*}{ Health-related behaviors } & \multicolumn{4}{|c|}{ Self-rated health } & \multirow{3}{*}{$p$-value ${ }^{a}$} \\
\hline & \multicolumn{2}{|c|}{ Negative } & \multicolumn{2}{|c|}{ Positive } & \\
\hline & $\mathrm{n}$ & $\%$ & $\mathrm{n}$ & $\%$ & \\
\hline \multicolumn{6}{|c|}{$\begin{array}{l}\text { Frequency of physical exercise in leisure time in the } \\
\text { past } 90 \text { days }\end{array}$} \\
\hline$<3$ times a week & 174 & 21.6 & 633 & 78.4 & \multirow{2}{*}{0.005} \\
\hline$\geq 3$ times a week & 15 & 11.1 & 120 & 88.9 & \\
\hline \multicolumn{6}{|l|}{ History of tobacco consumption } \\
\hline Never smoked & 99 & 17.1 & 480 & 82.9 & \multirow{3}{*}{$<0.001$} \\
\hline Former smoker & 41 & 19.0 & 175 & 81.0 & \\
\hline Current smoker & 49 & 33.8 & 96 & 66.2 & \\
\hline \multicolumn{6}{|c|}{ History of alcohol consumption in the last 12 months } \\
\hline Did not drink / never drank & 162 & 21.4 & 594 & 78.6 & \multirow{3}{*}{0.030} \\
\hline$<3$ times a week & 15 & 11.5 & 116 & 88.6 & \\
\hline$\geq 3$ times a week & 12 & 21.8 & 43 & 78.2 & \\
\hline
\end{tabular}

abtained by Chi-square Pearson.

a Obtido pelo teste do Qui-Quadrado de Pearson.

of negative self-rated health was significantly higher among those with a history of hospitalization in the last 12 months and among those who visited a doctor in the same period, as well as among those who reported having faced some problem (distance, price of consultation or long queue) when needing access to medical services (in all cases, $\mathrm{p}<0.001$ ). Those with health plan coverage showed a milder negative self-rated health compared to those without it $(\mathrm{p}=0.002)$ (Table 4$)$.

In Table 5, the final results of the multivariate analysis of factors associated with self-rated health are described. Compared to elderly with family income lower than two minimum wages, those with higher family income had a lower prevalence of negative self-rated health: $\mathrm{PR}=0.68$ (95\%CI $0.53-0.88)$ for income between 2 to 3.9 minimum wages and PR $=0.52(95 \% \mathrm{CI} 0.36-0.73)$ for those with income of 4 minimum wages or higher. Independent and positive associations with a negative self-rated health observed were dissatisfaction with social relations $(\mathrm{PR}=1.98,95 \% \mathrm{CI} 1.42-2.76)$, attendance at religious services less than once a month (PR $=1.96,95 \% \mathrm{CI} 1.44-2.68)$ and smoking $(\mathrm{PR}=1.64,95 \% \mathrm{CI} 1.24-2.17)$. Having arthritis or rheumatism (PR=1.35, 95\%CI 1.07 - 1.71), suffering from depression and anxiety symptoms ( $\mathrm{PR}=1.81,95 \% \mathrm{CI} 1.37-2.39$ ) and having had insomnia in the last 30 days ( $\mathrm{PR}=1.37$, CI95\% 1.06 - 1.78) were the health conditions that remained independently and positively associated with negative self-rated health. Being both hypertensive and diabetic (compared to being only hypertensive) was independently and positively associated with a poor self-rated health ( $\mathrm{PR}=1.4395 \% \mathrm{CI}$ 1.07 - 1.92). With regard to the use of health services, having had two or more medical appointments in the last 12 months ( $\mathrm{PR}=2.18$ 95\%CI $1.14-4.19$ and PR $=3.96$ 95\%CI 2.10 7.48 , respectively, for " $2-3$ " and " $4+$ " appointments) remained independently associated only with negative self-rated health.

\section{Discussion}

The results of this investigation showed that all dimensions investigated 
Table 3 - Distribution of self-rated health among hypertensive and/or diabetic elderly, according to health conditions, physical functioning and status in relation to hypertension and diabetes, Bambuí, Minas Gerais, 1997.

Tabela 3 - Distribuição da autoavaliação da saúde entre idosos hipertensos e/ou diabéticos, segundo condições de saúde, funcionalidade física e status em relação à hipertensão e diabetes, Bambuí, Minas Gerais, 1997.

\begin{tabular}{|c|c|c|c|c|c|}
\hline \multirow{3}{*}{ Variables } & \multicolumn{4}{|c|}{ Self-rated health } & \multirow{3}{*}{$p$-value } \\
\hline & \multicolumn{2}{|c|}{ Negative } & \multicolumn{2}{|c|}{ Positive } & \\
\hline & $\mathrm{n}$ & $\%$ & $\mathrm{n}$ & $\%$ & \\
\hline \multicolumn{6}{|l|}{ Coronary disease $^{b}$} \\
\hline No & 156 & 19.2 & 656 & 80.8 & \multirow{2}{*}{0.180} \\
\hline Yes & 30 & 24.4 & 93 & 75.6 & \\
\hline \multicolumn{6}{|l|}{ Arthritis and rheumatism } \\
\hline No & 108 & 17.1 & 523 & 82.9 & \multirow{2}{*}{0.001} \\
\hline Yes & 81 & 26.1 & 229 & 73.9 & \\
\hline \multicolumn{6}{|c|}{ Presence of antibodies to Trypanosoma cruzi } \\
\hline No & 95 & 16.4 & 484 & 83.6 & \multirow{2}{*}{0.001} \\
\hline Yes & 84 & 25.9 & 241 & 74.2 & \\
\hline \multicolumn{6}{|c|}{ Depression and anxiety symptoms in the last 15 days } \\
\hline No & 69 & 11.9 & 511 & 88.1 & \multirow{2}{*}{$<0.001$} \\
\hline Yes & 118 & 32.8 & 242 & 67.2 & \\
\hline \multicolumn{6}{|l|}{ Insomnia in the last 30 days } \\
\hline No & 81 & 14.7 & 471 & 85.3 & \multirow{2}{*}{$<0.001$} \\
\hline Yes & 106 & 27.3 & 282 & 72.7 & \\
\hline \multicolumn{6}{|c|}{ Presence of cognitive dysfunction } \\
\hline No & 129 & 17.0 & 628 & 83.0 & \multirow{2}{*}{$<0.001$} \\
\hline Yes & 58 & 31.9 & 124 & 68.1 & \\
\hline \multicolumn{6}{|c|}{ Number of prescribed drugs consumed in the last 90 days } \\
\hline None & 16 & 11.6 & 122 & 88.4 & \multirow{4}{*}{$<0.001$} \\
\hline 1 & 13 & 10.8 & 107 & 89.2 & \\
\hline $2-4$ & 73 & 17.4 & 347 & 82.6 & \\
\hline 5 or more & 87 & 33.0 & 177 & 67.1 & \\
\hline \multicolumn{6}{|c|}{ Inability to perform at least one activity of daily living } \\
\hline No & 151 & 18.0 & 686 & 82.0 & \multirow{2}{*}{$<0.001$} \\
\hline Yes & 37 & 35.9 & 66 & 64.1 & \\
\hline \multicolumn{6}{|c|}{ Participant status in relation to hypertension and diabetes } \\
\hline Only hypertension & 137 & 18.8 & 593 & 81.2 & \multirow{3}{*}{0.129} \\
\hline Only diabetes & 13 & 21.0 & 49 & 79.0 & \\
\hline Hypertension and diabetes & 39 & 26.0 & 111 & 74.0 & \\
\hline
\end{tabular}

${ }^{a}$ Obtained by Chi-square Pearson; bAngina and/or Myocardial Infarction.

${ }^{a}$ Obtido pelo teste do Qui-Quadrado de Pearson; ${ }^{b}$ Angina e/ou Infarto do Miocárdio.

- socio-demographic, social relations, lifestyle, health conditions and use of health services - are part of the structure of selfrated health in elderly people with hypertension and/or diabetes. In this respect, results observed in this population are similar to those observed in the total elderly population, which also included elderly people without these diseases ${ }^{11}$.
Having seen a doctor two or more times was the characteristic most strongly associated with a negative self-rated health among hypertensive and/or diabetic elderly. The positive association between poor selfrated health and medical appointments is present in other populations ${ }^{23-25}$ and in the total population of the elderly in Bambuí ${ }^{11}$. This association seems to have a bidirectional 
Table 4 - Distribution of self-rated health among hypertensive and/or diabetic elderly, according to some characteristics related to the use of health services, Bambuí, Minas Gerais, 1997.

Tabela 4 - Distribuição da autoavaliação da saúde entre idosos hipertensos e/ou diabéticos, segundo algumas características relacionadas à utilização de serviços de saúde, Bambuí, Minas Gerais, 1997.

\begin{tabular}{|c|c|c|c|c|c|}
\hline \multirow{3}{*}{ Health-related behaviors } & \multicolumn{4}{|c|}{ Self-rated health } & \multirow{3}{*}{$p$-value } \\
\hline & \multicolumn{2}{|c|}{ Negative } & \multicolumn{2}{|c|}{ Positive } & \\
\hline & $\mathrm{n}$ & $\%$ & $\mathrm{n}$ & $\%$ & \\
\hline \multicolumn{6}{|c|}{ History of hospitalization in the last 12 months } \\
\hline No & 117 & 16.1 & 609 & 83.9 & \multirow{2}{*}{$<0.001$} \\
\hline Yes & 72 & 33.3 & 144 & 66.7 & \\
\hline \multicolumn{6}{|c|}{ Number of medical visits in the last 12 months } \\
\hline None & 9 & 6.1 & 138 & 93.9 & \multirow{4}{*}{$<0.001$} \\
\hline 1 & 29 & 14.4 & 173 & 85.6 & \\
\hline $2-3$ & 48 & 17.8 & 221 & 82.2 & \\
\hline 4 or more & 103 & 31.8 & 221 & 68.2 & \\
\hline \multicolumn{6}{|l|}{ Health plan coverage } \\
\hline No & 165 & 22.2 & 578 & 77.8 & \multirow{2}{*}{0.002} \\
\hline Yes & 24 & 12.1 & 175 & 87.9 & \\
\hline \multicolumn{6}{|c|}{$\begin{array}{l}\text { Main problem faced when in need of medical } \\
\text { services }\end{array}$} \\
\hline None & 37 & 11.7 & 279 & 88.3 & \multirow{3}{*}{$<0.001$} \\
\hline Distance, price, queue & 113 & 25.8 & 325 & 74.2 & \\
\hline Other & 38 & 20.5 & 147 & 79.5 & \\
\hline
\end{tabular}

abtained by Chi-square Pearson.

a Obtido pelo teste do Qui-Quadrado de Pearson.

aspect. In a longitudinal study conducted in Finland, self-rated health emerged as a consistent predictor of use of medical services $^{24}$. Otherwise, self-rated health can be determined by what the patient hears from the doctor during consultation ${ }^{8}$ and positive experiences with primary health care (especially with regard to access and interpersonal relationship) can positively influence self-rated health, especially when socioeconomic inequality is more evident ${ }^{26}$. The cross-sectional nature of this study does not allow defining if, in this population, self-rating determines or is determined by the use of health services. Anyway, for the managers of such services, this association is relevant: on the one hand, monitoring of self-rated health may be an important indicator of changes in the needs of demand for health services. On the other hand, ensuring quality health care can result in positive changes in the health expectations of these users. This question gains greater importance if we consider that for the hypertensive and diabetic, a constant monitoring by health services is crucial for disease control and prevention of the worsening of their health condition.

Chronic health conditions have been the factors most consistently associated with self-rated health ${ }^{25}$. In fact, populations with socio-cultural and organizational differences, as well as a different delivery of health services, present this pattern of association, whether in relation to comorbidities $^{12,25}$ or specific morbidities ${ }^{11,23,27}$. In the present study, negative self-rated health was associated with depressive symptoms, insomnia and arthritis/rheumatism, indicating that these seem to be the health conditions favored by elderly hypertensive and/or diabetic in judging their own health. These findings are also similar to that observed in the total elderly population of Bambuí1 ${ }^{11}$ : Also among them, depressive symptoms and insomnia showed similar associations in terms of strength and direction. Previous experience with the disease, or those arising from encounters with health professionals and observing 
Table 5 - Final results of the multivariate analysis of associated factors to self-rated health among hypertensive and/or diabetic elderly, Bambuí, Minas Gerais, 1997.

Tabela 5 - Resultados finais da análise multivariada dos fatores associados à autoavaliação da saúde entre idosos hipertensos e/ou diabéticos, Bambuí, Minas Gerais, 1997.

\begin{tabular}{|c|c|c|}
\hline Characteristics & PR & $95 \% \mathrm{Cl}$ \\
\hline \multicolumn{3}{|c|}{ Family income in Minimum Wages ${ }^{a}$} \\
\hline$<2$ & 1.00 & \\
\hline $2-3.9$ & 0.68 & $0.53-0.88$ \\
\hline$\geq 4$ & 0.52 & $0.36-0.73$ \\
\hline \multicolumn{3}{|c|}{ Level of satisfaction with social relations } \\
\hline Satisfied & 1.00 & \\
\hline Indifferent & 1.10 & $0.72-1.66$ \\
\hline Dissatisfied & 1.98 & $1.42-2.76$ \\
\hline \multicolumn{3}{|l|}{ Attendance to religious cults } \\
\hline Once a week or more & 1.00 & \\
\hline 1 - 3 times a month & 1.28 & $0.93-1.76$ \\
\hline Less than once a month & 1.96 & $1.44-2.68$ \\
\hline \multicolumn{3}{|l|}{ History of tobacco consumption } \\
\hline Never smoked & 1.00 & \\
\hline Former smoker & 1.06 & $0.78-1.45$ \\
\hline Current smoker & 1.64 & $1.24-2.17$ \\
\hline \multicolumn{3}{|l|}{ Arthritis or rheumatism } \\
\hline No & 1.00 & \\
\hline Yes & 1.35 & $1.07-1.71$ \\
\hline \multicolumn{3}{|c|}{ Depression and anxiety symptoms in the last 15 days } \\
\hline No & 1.00 & \\
\hline Yes & 1.81 & $1.37-2.39$ \\
\hline \multicolumn{3}{|l|}{ Insomnia in the last 30 days } \\
\hline No & 1.00 & \\
\hline Yes & 1.37 & $1.06-1.78$ \\
\hline \multicolumn{3}{|c|}{ Number of medical visits in the last 12 months } \\
\hline None & 1.00 & \\
\hline 1 & 1.81 & $0.90-3.62$ \\
\hline $2-3$ & 2.18 & $1.14-4.19$ \\
\hline 4 or more & 3.96 & $2.10-7.48$ \\
\hline \multicolumn{3}{|c|}{ Status in relation to hypertension and diabetes } \\
\hline Only hypertension & 1.00 & \\
\hline Only diabetes & 1.11 & $0.71-1.73$ \\
\hline Hypertension and diabetes & 1.43 & $1.07-1.92$ \\
\hline
\end{tabular}

PR (95\% Cl): prevalence ratios (Robust 95\% Confidence Interval), estimated by Poisson regression model and adjusted for all variables described in the table; ${ }^{a}$ National Minimum Wage in effect at the time of the study = R\$ 120.00; the analysis included 924 participants.

PR (95\%Cl): Razões de Prevalências (Intervalo de Confiança 95\% robusto), estimada pelo modelo de regressão de Poisson e ajustadas por todas as variáveis descritas na tabela; ${ }^{a}$ Salário Mínimo Nacional vigente à época do estudo $=R \$ 120,00 ;$ a análise incluiu 924 participantes.

the health of family and friends can be the basis of this association. According to Idler et al. ${ }^{9}$, these experiences shape individual knowledge about health and base subjective judgments about it.

No difference was found in self-rated health among non-diabetic hypertensive elderly and non-hypertensive diabetic elderly, but elderly, both hypertensive and diabetic, self-rated their own health poorly in comparison to the former, and the prevalence of negative self-rated health was $43 \%$ higher among the latter. It is known that the association between hypertension and diabetes increases cardiovascular mortality between $40 \%$ and $70 \%$ and accelerates the 
development of nephropathy ${ }^{28}$. Moreover, a strict control of blood pressure can mean an increase in the time interval without complications from these diseases, reducing costs of control and treatment, as well as their consequent mortality ${ }^{29}$. The control of blood pressure depends, in turn, on the patient's motivation to adhere to a healthy lifestyle and fulfill the therapeutic regimen ${ }^{5}$. Considering the association between selfrated health and motivation to deal with the health problems experienced ${ }^{7}$, the results of this study are of concern, because the elderly who negatively self-rated their health may be less likely to face these diseases, and therefore are at higher risk for complications.

In different studies with the elderly population, income and social class have become associated with self-rated health, with socioeconomically disadvantaged elderly self-rating their health poorly ${ }^{11,12,25,26,30}$. Our results show that the same occurs in the elderly with hypertension and/or diabetes residing in Bambuí. This association may reflect a greater perception of morbidity among people with lower income, which, in turn, is linked to the fear of negatively affecting the maintenance of their work force, a need that is most urgent among them ${ }^{12}$.

The multidimensional aspect of the self-rated health structure was completed in the observation of the association of this variable with health-related risk behaviors (in this case, smoking) and aspects of social support (in this case, dissatisfaction with social relationships and a lower attendance to religious cults). The association between smoking and negative self-rated health is consistent with the literature ${ }^{31,32}$ and indicates that ideas about health-related risk behaviors are considered in the patient's subjective self-rated health, regardless of the presence of diseases or health problems consequent to them ${ }^{31}$. The findings of this study associate dissatisfaction with personal relationships, a lower attendance to religious cults and the patient's negative judgment of their own health, and reinforce the importance of social support in determining the self-rated health, corroborating with what was observed in other populations $^{33,34}$. Considering some characteristics of the study population, such as age group (60 years or older), predominantly low level of education and the presence of diseases that require continuous care (hypertension and diabetes), this finding has greater importance in the light of evidence that a greater social integration can improve selfrated health in people with low education, retired people and those who face barriers to access health care services ${ }^{33}$.

An important limitation of this study relates to its cross-sectional nature, which restricts the reach of interpretation of the results, especially considering the associations with the use of health services and the presence of diseases. Given the impossibility of establishing diachrony between exposure and event, it is not possible to say whether the health conditions and use of health services determine or are determined by self-rated health. Moreover, the strength of this research lies in the fact that it is population-based, and follows the methodological steps for conducting fieldwork, such as standardization of tools and processes of data collection, and comprehensive training of data collectors ${ }^{15}$. Another positive point lies in the discrimination of chronic health conditions used as covariates. Similar to the study that involved the whole elderly population from Bambuí ${ }^{11}$ and differently from other studies that used the quantification of chronic diseases in an undifferentiated way ${ }^{12,32}$, it was possible to identify which health conditions among those included in the investigation impacted self-rated health somehow.

In summary, the results of this study are consistent with that seen in national ${ }^{11,12,30}$ and international ${ }^{23-26,31-34}$ studies on the subject and confirm the multidimensional structure of self-rated health observed in the total elderly population of Bambuí. The association between self-rated health and use of health services and social support should deserve special attention from health professionals. They point to the relevance of developing efforts to ensure the access to 
quality health care and to promote greater social integration in order to improve subjective health self-rating by hypertensive and/or diabetic elderly. This would increase the willingness of this population to adhere to treatment protocols and health-related behaviors that minimize the risk of a negative evolution of these diseases. Further, investigations are needed to know whether the results observed in this population are present in other affected populations who present these health conditions.

\section{References}

1. Carvalho JAM, Rodriguez-Wong LL. A transição da estrutura etária da população brasileira na primeira metade do século XXI. Cad Saude Publica 2008; 24(3): 597-605.

2. Lima-Costa MF, Loyola Filho AI, Matos DL. Tendências nas condições de saúde e uso de serviços de saúde entre idosos brasileiros: um estudo baseado na Pesquisa Nacional por Amostra de Domicílios (1998, 2003). Cad Saude Publica 2007; 23(10): 2467-78.

3. Loyola Filho AI, Matos DL, Giatti L, Afradique ME, Peixoto SV, Lima-Costa MF. Causas das internações hospitalares brasileiras no âmbito do Sistêmica Único de Saúde. Epidemiol Serv Saúde 2004, 13(4): 229-38.

4. Ferreira SRG; Moura EC; Malta DC; Sarno F. Frequência de hipertensão arterial e fatores associados: Brasil, 2006. Rev Saude Publica 2009; 43(Suppl 2): 98-106.

5. Sociedade Brasileira de Cardiologia/Sociedade Brasileira de Hipertensão/Sociedade Brasileira de Nefrologia. VI Diretrizes Brasileiras de Hipertensão. Arq Bras Cardiol. 2010; 95(1 Suppl.1): 1-51.

6. American Diabetes Association. Diagnosis and classification of diabetes mellitus. Diabetes Care 2010; 33(Suppl 1): S62-S69.

7. Idler E, Benyamini Y. Self-rated health and mortality: a review of twenty-seven community studies. J Health Soc Behav 1997; 38(1): 21-37.

8. Benyamini Y, Leventhal EA, Leventhal H. Elderly people's ratings of the importance of health-related factors to their self-assessments of health. Soc Sci Med 2003; 56(8): 1661-7.

9. Idler E, Leventhal H, McLaughlin J, Leventhal E. In sickness but not in health: self-ratings, identity, and mortality. J Health Soc Behav 2004; 45(3): 336-56.

10. Dasbach EJ, Klein R, Klein BEK, Moss SE. Self-rated health and mortality in people with diabetes. Am J Public Health 1994; 84(11): 1775-9.

11. Lima-Costa MF, Firmo JOA, Uchoa E. A estrutura da auto-avaliação da saúde entre idosos: Projeto Bambuí. Rev Saude Publica 2004; 38(6): 827-34.

12. Alves LC, Rodrigues RN. Determinantes da auto-percepção de saúde entre idosos do município de São Paulo, Brasil. Rev Panam Salud Publica 2005; 17(5-6): 333-41.

13. Silva RJ, Smith-Menezes A, Tribess S, Rómo-Perez V, Virtuoso JS Jr. Prevalência e fatores associados à percepção negativa da saúde em pessoas idosas do Brasil. Rev Bras Epidemiol 2012; 15(1): 49-62.

14. Lima-Costa MF, Firmo JOA, Uchoa E. Differences in self-rated health among older adults according to socioeconomic circumstances: the Bambuí Health and Aging Study. Cad Saude Publica 2005; 21(3): 830-9.

15. Costa MF, Uchoa E, Guerra HL, Firmo JOA, Vidigal PG, Barreto SM. The Bambuí Health and Ageing Study 9BHAS): methodological approach and preliminary results of a population-based cohort study of the elderly in Brazil. Rev Saude Publica 2000; 34(2): 126-35.

16. Goldberg DP, Hillier VF. A scaled version of the General Health Questionnaire. Psychol Med 1979; 9(1): 139-45.

17. Mari JJ, Williams P. A comparison of the validity of two psychiatric screening questionnaires (GHQ-12 and SRQ-20) in Brazil, using Relative Operating Characteristic (ROC) analysis. Psychol Med 1985; 15(3): 651-9.

18. Costa E, Barreto SM, Uchoa E, Firmo JOA, Lima-Costa MF, Prince M. Is the GDS-30 better than the GHQ-12 for screening depression in elderly people in the community? The Bambuí Health Aging Study (BHAS). Int Psychogeriatr 2006; 18(3): 493-503.

19. Rocha FL, Guerra HL, Lima-Costa MF. Prevalence of insomnia and associated socio-demographic factors in a Brazilian community: the Bambui study. Sleep Med 2002; 3(2): 121-6.

20. Folstein MF, Folstein SE, McHugh PR. "Mini-Mental State": a practical method for grading the cognitive state of patients for the clinician. J Psychiatr Res 1975; 12(3): 189-98.

21. Castro-Costa E, Fuzikawa C, Uchoa E, Firmo JO, Lima-Costa MF. Norms for the Mini-Mental State examination: adjustment of the cut-off point in population-based studies (evidences from The Bambuí Health Aging Study). Arq Neuropsiquiatr 2008; 66(3-A): 524-8.

22. Long JS, Freese J. Regression models for categorical dependent variables using Stata. $2^{\text {nd }}$ ed. Texas: Stata Press, College Station; 2006.

23. Smith PM, Glazier RH, Sibley LM. The predictors of self-rated health and the relationship between self-rated health and health service needs are similar across socioeconomic groups in Canada. J Clin Epidemiol 2010; 63(4): 412-21. 
24. Miilumpalo S, Vuori I, Oja P, Pasanen M, Urponen H. Self-rated health status as a health measure: the predictive value of self-reported health status on the use of physician services and on mortality in the working-age population. J Clin Epidemiol 1997; 50(5): 517-28.

25. Damian J, Ruigomez A, Pastor V, Martin-Moreno JM. Determinants of self assessed health among Spanish older people living at home. J Epidemiol Community Health 1999; 53(7): 412-6.

26. Shi L, Starfield B, Politzer R, Regan J. Primary care, self-rated health, and reductions in social disparities in health. Health Serv Res 2002; 37(3): 529-50.

27. Molarius A, Janson S. Self-rated health, chronic diseases, and symptoms among middle-aged and elderly men and women. J Clin Epidemiol 2002; 55(4): 364-70.

28. Espuny JLC. Diabetes e hypertension: uma epidemia creciente y costosa. Atención Primaria 2006; 38(10): 542-3.

29. UK Prospective Diabetes Study Group. Cost effectiveness analysis in improved blood pressure control in hypertension patients with type 2 diabetes. BMJ 1998; 317(7160): 720-6.

30. Lima-Costa MF, Barreto S, Giatti L, Uchoa E. Desigualdade social e saúde entre idosos brasileiros: um estudo baseado na Pesquisa Nacional por Amostra de Domicílios (PNAD). Cad Saude Publica 2003; 19(3): 745-57.

31. Manderbacka K, Lundberg O, Martikainen P. Do risk factors and health behaviours contribute to self-rating of health? Soc Sci Med 1999; 48(12): 1713-20.

32. Cott CA, Gignac MA, Badley EM. Determinants of self rated health for Canadians with chronic disease and disability. J Epidemiol Community Health 1999; 53(11): 731-6.

33. Gorman BK, Sivaganesan A. The role of social support and integration for understanding socioeconomic disparities in self-rated health and hypertension. Soc Sci Med 2007; 65(5): 958-75.

34. Melchior M, Berkman LF, Niedhammer I, Chea M, Goldberg $\mathrm{M}$. Social relations and self-reported health: a prospective analysis of the French Gazel cohort. Soc Sci Med 2003; 56(8): 1817-30.
Received on: 12/13/11

Final version presented on: 06/15/12

Accepted on: 10/31/12 